\title{
Enterobius vermicularis, the small human pinworm: a chronic infestation diagnosed by Pillcam. Incidental observation on Capsule Endoscopy
}

\author{
Riccardo Urgesi, ${ }^{1,2}$ Maria Elena Riccioni, ${ }^{1}$ Cristiano Spada, ${ }^{1}$ Giorgio Pelecca, ${ }^{2}$ Guido Costamagna ${ }^{1}$ \\ ${ }^{1}$ Digestive Endoscopy Unit, Catholic University, Rome, Italy \\ ${ }^{2}$ Gastroenterology Unit, BelColle, Viterbo, Italy \\ Correspondence to Riccardo Urgesi, riurgesi@tin.it
}

\section{DESCRIPTION}

A 35-year-old male presented complaints of cramps, diarrhoea, lower abdominal pain, mild iron-deficiency anaemia but without weight loss, nausea, vomiting or gastrointestinal bleeding. Gastroscopy, colonoscopy, small bowel follow-through, laboratory data and faecal microscopy were normal. At capsule endoscopy, multiple small live worms compatible with Enterobius vermicularis were identified. They had the appearance of pinworms (figure 1 and video), approximately $4-\mathrm{mm}$ long and swam in the distal jejunum and ileum. The mucosa throughout small bowel was endoscopically normal. Histopathology of the worms confirmed it to be an Evermicularis. At the time of follow-up, after treatment with albendazole $400 \mathrm{mg}$ once a day for 3 days and iron supplements symptoms had completely disappeared. The adult worms are small; the females are larger than the males and typically range from 8 to $13 \mathrm{~mm}$. They live mainly in the caecum and have been seen in the appendix. The eggs of these warms are spread by the faecal-oral route to both the original host and new hosts. Once the eggs are ingested, they hatch in the duodenum and the larvae mature as they migrate to the colon over a few weeks. The most cases of $E$ vermicularis are asymptomatic. The main symptom is perianal itching and can be due to mechanical stimulation, irritation or allergic manifestations. The diagnosis is generally made by the "Scotch tape" or "cellophane tape" test. The sensitivity of the test is $90 \%$. This test should be done as the first thing in the morning, before a shower or bath and because $E$ vermicularis is easily spread throughout households.

Video $1 \quad$ 10.1136/bcr.09.2009.2258v1

Competing interests None.

Patient consent Obtained.

\section{REFERENCES}

1. Russell LJ. The pinworm, Enterobius vermicularis. Prim Care 1991;18:13.

2. Dalimi A, Khoshzaban F. Comparative study of two methods for the diagnosis of Enterobius vermicularis in the appendix. $J$ Helminthol 1993;67:85-6.

3. Fernandez-Flores A, Dajil S. Enterobiasis mimicking Crohnqrquo;s disease. Indian J Gastroentero/ 2004;23:149-50.

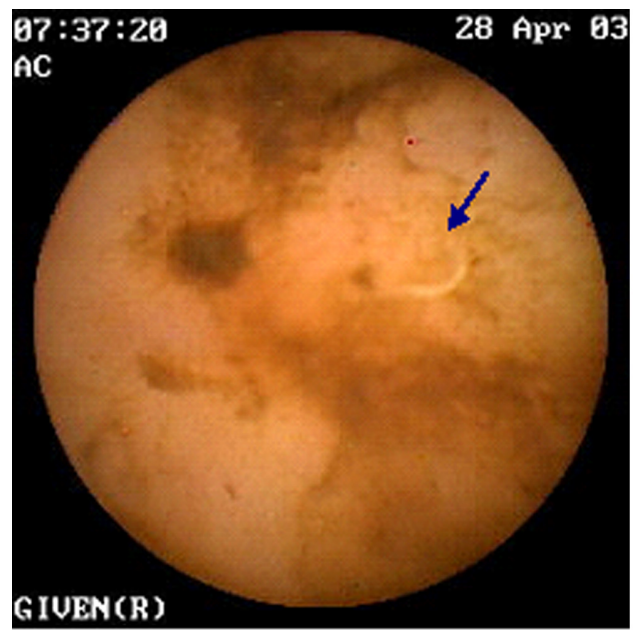

Figure 1 and video Evermicularis swimming in the colon.

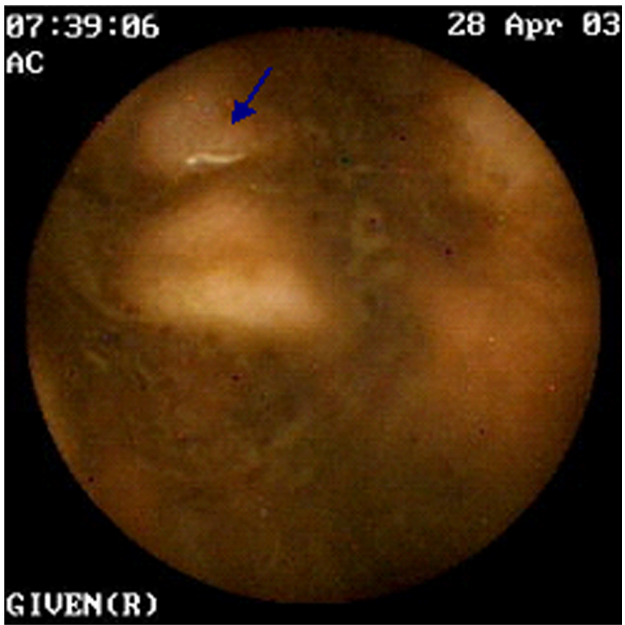




\section{BMJ Case Reports}

This pdf has been created automatically from the final edited text and images.

Copyright 2010 BMJ Publishing Group. All rights reserved. For permission to reuse any of this content visit http://group.bmj.com/group/rights-licensing/permissions.

BMJ Case Report Fellows may re-use this article for personal use and teaching without any further permission.

Please cite this article as follows (you will need to access the article online to obtain the date of publication).

Urgesi R, Riccioni ME, Spada C, Pelecca G, Costamagna G. Enterobius vermicularis, the small human pinworm: a chronic infestation diagnosed by Pillcam. Incidental observation on Capsule Endoscopy. BMJ Case Reports 2010;10.1136/bcr.09.2009.2258, date of publication

Become a Fellow of BMJ Case Reports today and you can:

- Submit as many cases as you like

Enjoy fast sympathetic peer review and rapid publication of accepted articles

Access all the published articles

Re-use any of the published material for personal use and teaching without further permission

For information on Institutional Fellowships contact consortiasales@bmjgroup.com

Visit casereports.bmj.com for more articles like this and to become a Fellow 